\title{
Methyprednisolone i.v. alters levels of CGRP and melatonin in cluster headache patients
}

\author{
L Neeb", L Anders, P Euskirchen, J Hoffmann, U Reuter \\ From The European Headache and Migraine Trust International Congress \\ London, UK. 20-23 September 2012
}

\begin{abstract}
Introduction
Treatment with steroids for short term cluster headache $(\mathrm{CH})$ prophylaxis is a widely accepted therapy. However, the mechanism of action of steroids in $\mathrm{CH}$ prophylaxis is unknown. Various studies could show that the trigeminovascular system and the hypothalamus play probably a key role in $\mathrm{CH}$ pathophysiology. The neuropeptid calcitonin gene related peptide (CGRP) is released in an acute attack indicating activation of the trigeminovasclular system.[1] The hypothalamus regulates the circadian secretion of melatonin which is reduced in $\mathrm{CH}$ patients during a bout.[2]
\end{abstract}

\section{Objective}

The aim of this study was to assess if treatment with high dose methylprednisolone (MP) i.v. inhibits release of CGRP and influences secretion of melatonin in $\mathrm{CH}$.

\section{Methods}

10 patients with episodic Cluster headache and 5 control patients with an acute episode of multiple sclerosis (MS) who should receive MP i.v. were included in the study. Patients were treated at the beginning of an episode $(\mathrm{CH}$ or MS) with a course of once daily $1 \mathrm{~g}$ MP i.v. for three days followed by oral tapering. CGRP was assessed in plasma of the external jugular vein and the metabolite of melatonin in urine - 6-sulfatoxymelatonin - was collected separately during the day and night. Measurements were done before as well as one day, one and two weeks after start of treatment. Patients recorded the number and severity of headache attacks each day.

\section{Results}

Treatment with MP led to a transient and significant decline of headache frequency. Simultaneously, CGRP plasma levels were reduced up to one week after end of treatment. Secretion of melatonin increased one and two weeks after treatment significantly. No significant changes could be observed in the control group.

\section{Conclusion}

The results could point to a possible mechanism of action of steroids in cluster headache prophylaxis. The altered secretion pattern could be explained through a direct effect of MP on the trigeminovascular system and the hypothalamus but could also be a consequence of the reduced frequency of attacks.

Published: 21 February 2013

\section{References}

1. Goadsby PJ, Edvinsson L: Human in vivo evidence for trigeminovascular activation in cluster headache. Neuropeptide changes and effects of acute attacks therapies. Brain 1994, 117(Pt 3):427-34.

2. Leone M, Lucini V, D'Amico D, Grazzi L, Moschiano F, Fraschini F, et al: Abnormal 24-hour urinary excretory pattern of 6-sulphatoxymelatonin in both phases of cluster headache. Cephalalgia 1998, 18(10):664-7.

doi:10.1186/1129-2377-14-S1-P63

Cite this article as: Neeb et al:: Methyprednisolone i.v. alters levels of CGRP and melatonin in cluster headache patients. The Journal of Headache and Pain 2013 14(Suppl 1):P63.

Submit your manuscript to a SpringerOpen ${ }^{\bullet}$ journal and benefit from:

- Convenient online submission

- Rigorous peer review

- Immediate publication on acceptance

- Open access: articles freely available online

- High visibility within the field

Retaining the copyright to your article

Submit your next manuscript at $>$ springeropen.com 